\title{
Foibe literature: documentation or victimhood narrative?
}

\author{
Louise Zamparutti University of Wisconsin-Milwaukee \\ zamparu2@uwm.edu
}

\begin{abstract}
This essay analyses the literature on the foibe to illustrate a political use of human remains. The foibe are the deep karstic pits in Istria and around Trieste where Yugoslavian Communist troops disposed of Italians they executed en masse during World War II. By comparing contemporary literature on the foibe to a selection of archival reports of foibe exhumation processes it will be argued that the foibe literature popular in Italy today serves a political rather than informational purpose. Counterpublic theory will be applied to examine how the recent increase in popular foibe literature brought the identity of the esuli, one of Italy's subaltern counterpublics, to the national stage. The paper argues that by employing the narrative structure of the Holocaust, contemporary literature on the foibe attempts to recast Italy as a counterpublic in the wider European public sphere, presenting Italy as an unrecognised victim in World War II.
\end{abstract}

Key words: foibe, massacres, corpses, Communism, counterpublic, victimhood, Fascism

\section{Introduction}

The mass graves in the deep pit-caves known as the foibe in the Istrian peninsula and the Venezia Giulia region have received a large amount of attention in Italy since the end of the Cold War and the collapse of Yugoslavia. Information about their discovery and exhumation, however, is obscured by the ethno-political polemic surrounding how they should be memorialised. It is known that the foibe massacres occurred in two major waves, the first in the Istrian region in September and October 1943, and the second in and around Trieste immediately following Liberation in May 1945. Both waves of massacres are attributed to Yugoslavian Communist partisans whose main objective was to occupy and take control of the areas. The 1943 killings are thought to have been of a more spontaneous, unorganised nature as partisan troops surged into the Istrian peninsula, while the 1945 massacres were the result of an organised and systematised process of arrests, trials and executions. ${ }^{1}$ 
Reports of the numbers of victims and their identities vary widely due to the diverse conditions of the caves as well as heterogeneous interpretations of the motivations behind the massacres, which influence speculations about the caves' contents. Although these divergent accounts reflect the political affiliations of those reporting, the prevailing interpretation of the foibe massacres since the end of the Cold War has changed from that of a politically motivated resa dei cont ${ }^{2}$ to a human-rights issue, described by some as acts of 'ethnic cleansing'. ${ }^{3}$

Since the mid-1990s the amount of literature on the foibe has greatly increased. Rather than bringing to light submerged events, however, the emergence of a new genre of foibe literature has further obfuscated the facts, mixing fiction and myth with hard evidence. Furthermore, while the foibe massacres are remembered today as human rights violations based on ethnic differences, political undertones remain firmly in place, disjointedly pairing ethnic Slavs with Communism and ethnic Italians with 'democracy' or anti-Communism, despite the supposed end of Cold War dynamics in the region. This pairing, superimposed on the designation by some political factions of the foibe killings as acts of 'ethnic cleansing', has fuelled the development of an ongoing contentious debate over how the foibe should be memorialised, leaving little room for investigation and discussion of the actual exhumations of the corpses.

The paper begins with a brief overview of the region's complicated ethnic and political background, highlighting the major changes in political rule and national borders. For additional information to that provided here, detailed examinations of the history of the Italy-Slovenia-Croatia border region can be found in the works of authors such as Moodie ${ }^{4}$ and more recently Unger and Šegulja ${ }^{5}$, Sluga ${ }^{6}$, Ballinger ${ }^{7}$ and in the edited volume of Michieli and Zelco. ${ }^{8}$ From an Italian history perspective the history of the region has been re-examined to some extent by Ginsborg ${ }^{9}$ and Foot. ${ }^{10}$ The brief overview here aims primarily to contextualise the analysis of foibe archival information and foibe literature. Archival information on the discovery and exhumation of the foibe will then be presented. ${ }^{11}$

Because archival information has been meshed with political rhetoric and dramatised stories of questionable origin in popular foibe literature, a new investigation of the archival documents on foibe discovery and exhumation is warranted, and this paper presents an initial inquiry. A future investigation of Italian, Slovenian and Croatian archives is a necessary next step in the continuation of this research. The archival research presented here reveals the degree to which this original source material has been selected and modified in popular literature to serve a political purpose. Re-examination of archival information on corpses from mass graves provides new opportunities to re-evaluate current perceptions of instances of mass violence; in the case of the Istrian foibe, it provides a wider perspective on the recent profusion of highly politicised literature and divergent interpretations.

After presenting the archival information, recent foibe literature will be reviewed, first to analyse the validity of this literature's sources, and then to examine how this literature is influential in transferring the counterpublic status of the esuli to all of Italy. ${ }^{12}$ Literature has been chosen that most clearly represents the dominant voices of foibe discourse in Italy today, voices which originate primarily from right-wing 
nationalist parties, exemplified by authors such as Petacco ${ }^{13}$, Oliva ${ }^{14}$, Toth ${ }^{15}$ and Mellace. ${ }^{16}$ A smaller group of more obscure and less widely-read foibe literature will also be analysed that counters the claims made by the larger, more popular body of literature. These examples stem primarily from the left, and often from members of Italy's Slovene and Croat minorities, such as Alessandra Kersevan ${ }^{17}$, Claudia Cernigoi ${ }^{18}$ and Sandi Volk. ${ }^{19}$ It is the intention that the analysis of these two bodies of literature, paying close attention to narrative structure, language use and referenced sources, and comparison of both to archival information will show how the political divide between bodies of literature has reduced inquiry and discussion to defensive claims of victimhood status and refutations of the other side's arguments. For this reason, re-examination of archival documents on the foibe is valuable and necessary at this time.

\section{Historical background}

The Istrian peninsula and the area around Trieste where foibe were discovered is a region characterised by both an intermingling of ethnicities and tenacious claims of autochthony by so-called 'pure' ethnic groups, most notably, and especially in foibe literature, divided into the categories 'Slavic' and 'Italian'. The region's linguistic, ethnic and political diversity as well as numerous shifts in border demarcations explain why various groups in this region have historically seen themselves as counterpublics. Slovenes and Croats saw themselves as excluded minorities during the interwar period when Fascist Italy controlled the region; Istrian Italians saw themselves as a counterpublic after World War II when Istria was allocated to Yugoslavia.

During World War II, after the collapse of the Italian military system when Italy signed the Armistice with the Allies in September 1943, Yugoslavian Communist partisans surged into Istria in an attack aimed to eliminate the Fascist presence in the area. It was during this insurrection that people were rounded up and executed, and their corpses deposited into foibe. Popular literature in Italy claims that these foibe victims were Italian citizens, the majority of them innocent villagers executed solely because of their ethnic identity as Italians. Other literature refutes this interpretation, stating that corpses found in the foibe were those of a wide range of people of different nationalities and ethnicities: Nazi and Fascist political and military leaders, members of the upper classes and Slovene and Croat landowners and industrialists, as well as Italian and Yugoslavian antifascist partisans who deposited their own fallen soldiers in the foibe to prevent discovery of their locations and to avoid retaliation on partisans' families if they were found. ${ }^{20}$

This divergence in interpretation is facilitated by several factors particular to the region's circumstances in World War II. One factor is the inaccuracy of official documentation of individuals living in the area at the time of this partisan insurrection, due to the widespread unofficial relocation that had been taking place in response to advancing German forces and invasions by Chetniks and Ustašas. Many of the civilian evacuees from different areas of Italy and Yugoslavia had no official identification. Additionally, when Italy capitulated, troops from many 
different regions of Italy who had been stationed in Istria scattered in attempts to flee German forces, who had overnight become their new enemies, and these Italian troops were also targeted by the Communist partisan forces. A third factor is that no organised, systematic or documented exhumation processes took place at this time; the discovery of caves containing corpses was not well documented. Foibe literature therefore freely argues both for and against different motivations for the massacres and different numbers and identities of victims, due to a lack of official documentation.

A second wave of foibe massacres occurred in the area around Trieste after the collapse of German forces in May 1945. By this time the Yugoslavian Communist troops were a highly organised front, and advanced into Trieste in a race to 'liberate' or 'occupy' the region - the term varies depending on the literature - before Anglo-American forces reached the area. Although this wave of foibe killings, unlike that of 1943, was an organised and systematic process of arrests and executions carried out by the Odeljenje za zaštitu naroda (Department for the Protection of the People), or OZNA, which had been formed in the spring of 1944, documentation of people on those arrest lists is scarce. ${ }^{21}$ While some literature states that OZNA arrested German and Italian Nazi and Fascist collaborators, Chetniks, Ustašas, Domobrani (Croatian Home Guards), Cossacks and many others deemed to be enemies of the Yugoslavian Communists, ${ }^{22}$ the predominant interpretation advanced by popular foibe literature is that these foibe killings were ethnically motivated crimes against Italians.

Italy's loss of Istria after the war led to a mass exodus of Italians from the region over a period of about fifteen years and galvanised a counterpublic identity for Istrian Italians and for many Italians residing along Italy's northeastern border. Trieste remained under Allied rule while both Italian and Yugoslavian leaders made the case for territorial annexation, further fueling a counterpublic identity for Triestine Italians who felt their national identity was threatened by the prospect of losing Trieste. ${ }^{23}$ For the esuli, the loss of their homeland represented a continuation of the violence of the foibe, motivated by the same Yugoslavian plan to eliminate Italians. Many examples of popular foibe literature build on this association and count the esuli among the infoibati, ${ }^{24}$ which significantly increases the numbers of 'victims' and reinforces a narrative of victimhood and minority discourse. The foibe and the exodus understandably encompass a joined collective memory of suffering and victimhood for Istrian Italians, and this sentiment has been employed in popular literature and applied to all Italians. This has facilitated the adoption on a national scale of the collective suffering that was once only the domain of the esuli in Trieste.

National recognition and internalisation of the traumas experienced by the esuli was not solely through their own lobbying, however, but due to local and national political voices that emerged in the mid-1990s. As Asen argues, counterpublic status can be claimed for political purposes and should be considered relative to 'how invocations of counterpublicity serve various interests and agendas'. ${ }^{25}$ By aligning with the Istrian exile community and sharing its collective memory of victimhood, Italy claimed counterpublic status to serve a political and national 
agenda, that of re-inventing national identity after the political crises of the early 1990s. Popular foibe literature promoted this through a narrative style that mirrors Holocaust literature, constructing a 'Holocaustisation' ${ }^{26}$ of the foibe. These narratives are far removed from archival source materials, however. A re-examination of archival documents sheds new light on the role foibe literature plays in the overlap of historiography and politics in Italy.

\section{Archival information}

Scarcity of documented arrest lists combined with the small number of caves discovered and corpses exhumed from them reveal the discrepancy between the facts presented in the archives and those described in popular foibe literature. Documents from the American forces stationed in Italy report that aside from the discovery of corpses in several caves around Trieste, most attempts at exhumation were unsuccessful. Alexander Comstock Kirk, an American political advisor named Ambassador to Italy in 1944, states in a telegram from 22 June 1945 to the United States Secretary of State that he received reports from British military personnel that

there is a large pit approximately 1000 feet deep within the area desired by the Yugos in Venezia Giulia. It is declared by inhabitants of this area that the Yugos had shot hundreds of Italians whose corpses they threw into the pit, then shot several hundred German POWs whose bodies were thrown over the Italians. The Yugos then shot a number of horses whose carcasses were also dropped over the bodies of the human beings in the pit. The British ordered an investigation into this matter and although the inquiry is not yet complete, they received a report just two hours before this meeting that grappling hooks dropped down had produced human flesh. ${ }^{27}$

An American military report from the Eighth Army Headquarters dated 1 July 1945 states that investigations were being carried out regarding similar allegations from the CLN (Committees of National Liberation) in Trieste, who reported that Yugoslavians had thrown hundreds of corpses of Fascist officials and German soldiers, followed by horse carcasses, into an 800 foot-deep unused mine shaft in Basovizza (about 6.5 kilometers east of Trieste). The investigations, largely unproductive due to vapour in the shaft, did raise several items including 'an Italian greatcoat with bullet holes, bits of bone and fragments of weapons' covered with decaying flesh. The report recommends that investigations be closed and the shaft sealed due to the hazardous conditions and difficulty identifying any of the bodies in such a state of decomposition. ${ }^{28}$ Subsequent documents from 10 July 1945 further recommend its closing and sealing off the shaft opening. ${ }^{29}$

On 19 July, however, a memo was issued declaring that the site should be investigated once more, as it pertained to inquiries of war crimes against British and American personnel. Earlier that same day, a document had been received reporting that members of the Allied missions to the Partisans and Allied Air Crews that had been shot down by Germans 'were thrown into pits at RACIA. J 0748 
and MATTERIA. H 9965 East of the Morgan Line'. ${ }^{30}$ By 24 July an agreement had been made between Alexander, Eden and Churchill ordering a complete investigation of the Basovizza mine shaft. ${ }^{31}$ As the inquiries continued, another cable to the Secretary of State in Washington dated 16 July 1945 reports the 'discovery of a number of unidentified bodies in pit at Ternova Diccola ... according to a report from the British XIII Corps. Great difficulties expecting in recovery of the bodies and investigations are being carried out'. ${ }^{32}$ A subsequent memo from 6 September 1945 reiterates the findings cited above, yet they failed to produce any corpses that could be identified. ${ }^{33}$ By December 1945 deliberation over whether to attempt exhumation processes ended and the case was officially closed. ${ }^{34}$ Corpses were left in the pits and conclusive information regarding the victims' identities was never obtained.

As stated earlier, the archival research here does not include an investigation of documents from the former Yugoslavia, but correspondence with Slovenian speleologist Andrej Mihevc provides some useful anecdotal information. In unofficial explorations of foibe in Slovenia, Mihevc reports having found personal details, including 'parts of clothes, buttons, belt-buckles, parts of shoes and personal objects ... spoons, pocket-knives, pieces of pocket-mirrors and combs ... pieces of rosaries, Italian, German and also Serbian, Croatian and Albanian coins evidencing that also people of other nations died in that cave'. ${ }^{35}$ Mihevc points out that the discovery of some Italians among the corpses does not sufficiently imply that this was an Italian 'genocide', ${ }^{36}$ which raises the question of how the current interpretation of the foibe as an 'Italian genocide' is received by Slovenians and Croatians whose relatives may have perished in these massacres. An examination of both archival documents and foibe literature in Slovenia and Croatia would therefore be worthy of future research, and would provide an interesting juxtaposition to the Italian foibe literature, which has gained national attention and is the topic of the next section of this essay.

\section{Popular foibe literature: Holocaust narratives}

Most examples of recent foibe literature pay little heed to archival information and lack any specific information regarding locations and dates of foibe discoveries and exhumations. The disparity between archival information and the large body of popular foibe literature begins with a re-definition of the term foibe in the literature, a re-definition that is both constricted and broadened from the word adopted in the immediate post-war period. ${ }^{37}$ The word foibe and its associated term infoibati for the victims is constricted to signify only the killing of Italians by Yugoslavians, rather than including the elimination of other ethnic groups by other military forces. The word has also been generalised to include Italian victims of any kind of Yugoslavian-led violence. ${ }^{38}$ Popular foibe literature constructs a potentially offensive and highly questionable parallel between the violence of the foibe and the Nazi Holocaust. This parallel is reinforced by Italy's newest national holiday, Giorno del Ricordo, which commemorates victims of the foibe. The holiday, passed into law in 2004 and first celebrated nationally in 2005, falls on 10 February, 
marking the signing of the Treaty of Paris in 1947 that allocated the Istrian peninsula to Yugoslavia. This is a significant date for the esuli, as it marks the official loss of their homeland, but because it falls two weeks after International Holocaust Memorial Day on 27 January, the parallel between victims of the foibe and victims of the Holocaust can be more easily presented in foibe literature. Graphic imagery and vivid detail, reportedly based on eyewitness accounts but unsupported by any referenced sources, further facilitates popular acceptance of this parallel.

One of the first examples of this genre of foibe literature to emerge is the often cited 2003 work of Pupo and Spazzali, Foibe. This small but dense work, unlike much of the accompanying literature, does include some documentation from the Slovenian National Archives, and this information is presented alongside unreferenced essays by Pupo and Spazzali as well as several other authors, blurring the distinction between document and opinion. The authors do acknowledge that the definition of the term foibe has been widened to the extent that in collective memory the infoibati are considered to be all those killed by Slovene and Croat Communist partisans, by philo-Yugoslavic Italian Communist partisans and by the Yugoslavian authorities in the two crises of autumn 1943 and the spring and summer of 1945. ${ }^{39}$ Yet the authors argue nonetheless that the infoibati were primarily Italians, both military personnel and civilians, employing the constricted definition that excludes other ethnicities and nationalities (though they include 'philo-Yugoslavic' Italians among the perpetrators). ${ }^{40}$ Pupo and Spazzali's contextualisation of the 1943 and 1945 foibe killings as consequences of Italian and Slavic nationalistic conflicts during the final years of Hapsburg rule, ${ }^{41}$ occupation of Yugoslavia by the Italians ${ }^{42}$ and the region's annexation by the Third Reich, ${ }^{43}$ situates the foibe massacres as acts of revenge due to the use of the constricted definition of the massacres as Yugoslavians-killing-Italians. Their central argument is that the killings were a specifically Italian tragedy, despite evidence that many non-Italians were among the dead.

Lucio Toth furthers the Italian tragedy argument, clouding the distinction between fact and opinion even further and building on the victimhood narrative initiated by Pupo and Spazzali's earlier work. Toth presents the killings not only as an exclusively Italian experience but as a submerged history, adding to the tragedy of the crimes themselves an infliction from within Italy (from the left, that is) for keeping these crimes undercover. Toth attributes emerging discussion on the foibe and the trauma of the esuli to the 'ethnic cleansing that was reproduced in ex-Yugoslavia at the moment of the dissolution of the Socialist Federal Republic of Yugoslavia ... we thus see in the heart of Europe ... a re-explosion of ethnic and religious, or pseudo-religious, hatred'. ${ }^{44}$ His use of the word 'reproduced' positions the Yugoslavian violence of the 1990s as a return to the past, a return to the violence of the foibe. His argument is advanced by descriptions of the foibe killings detailed with images that mirror Holocaust narratives: villagers dying on death marches, people being thrown while still alive into the pits (recalling Babi Yar), and the forced removal of all clothing and personal items. According to personal testimonies, Toth states, 'victims were stripped of all objects of value and often of any articles of clothing, even undergarments, and thrown naked into the abyss', 
echoing the well-known descriptions and images of people traipsing into the gas chambers in Nazi concentration camps. ${ }^{45}$ In another example of Holocaust narrative, Toth describes prisoners, 'almost always on foot', being transferred from one camp to another, 'hauled across cities and towns like trophies in front of the population', among them those who were 'old, sick or wounded from beatings from the guards'. ${ }^{46}$ Though he cites no sources in reporting the numbers of Italian foibe victims exhumed from caves, he provides a quote from Spazzali stating that there were lists drawn up of 'no less than 16,000 names of persons arrested and charged with collaboration'. ${ }^{47}$ Pupo and Spazzali provide no source for this much quoted number, however.

Toth, however, goes much further than presenting the foibe as YugoslavianItalian ethnic violence. He sees the foibe as a manifestation of a much more longterm ethnic conflict between Slavs and Italians, with Slavs taking the role of the primary, and more virulent, aggressors. Toth argues that the Balkan Hotel, (known to Slovenians as the Narodni dom) in Trieste, a center of Slovene cultural activity that was attacked and burned by Fascists in 1920, was actually a place where 'Yugoslavian activists stored their arms and ammunition'. ${ }^{48}$ The two decades of Fascism preceding World War II he describes as a period of reciprocal violence and territorial struggles in the areas of Yugoslavia that were annexed by Italy, initiated primarily by Slovenes and Croats against Italians. 'Thousands of Italians', he argues, fled to escape Slavic violence. Toth paints a picture of preexisting antiItalianism that directly led to a campaign of 'ethnic cleansing' that stemmed from 'heightened nationalism' and 'totalitarian ideology'. ${ }^{49}$ Italy's identity as a counterpublic is thus presented as something that existed prior to the violence of the foibe. In Toth's view, even during the Fascist era the Italians in Istria and Dalmatia were an excluded and oppressed minority. Minority discourse is a theme running throughout Toth's narratives, and this theme has been swept up by many authors and pervades much subsequent foibe literature.

Petacco's Esodo: la tragedia degli italiani d'Istria, Dalmazia e Venezia Giulia is a prime example of this minority discourse theme. ${ }^{50}$ Undocumented claims presented in a narrative that mirrors Holocaust literature create an image mirroring that of Toth's, that Italian Istrians were an oppressed minority during the Fascist years. The section titled 'One martyr among the many' provides an Anne Frank equivalent in the story of Norma Cossetto. ${ }^{51}$ 'The death of Norma Cossetto', writes Petacco, 'is one of many dramatic episodes that symbolise the savage wave of violence brought down on the Italians of Venezia Giulia, Istria and Dalmatia'. ${ }^{52}$ With no cited sources or documentation, Petacco tells the story of the twenty-three year-old university student who, while conducting research in Istria in 1943 to prepare for her degree, was captured and arrested by Croatian Communists. Her father is described as a high-ranking Fascist official, and the possibility that he might be culpable in perpetrating Fascist violence is overshadowed by the details of Norma's graphic torture, sexual violence and subjugation to 'every kind of agony' in her 'excruciating via crucis'. ${ }^{53}$ After days of torture, Norma's mutilated corpse is thrown into a foiba. But she suffered and died per l'italianità dell'Istria, for Istrian Italian identity. ${ }^{54}$ Petacco meshes language of Christian martyrdom with 
Holocaust narrative to contribute to the formation of a counterpublic identity for Italians, using the familiar themes of villainous thugs persecuting symbols of innocence and purity (the ragazza, the young woman, the virgin), and the victim who dies for a cause (italianità).

The story of Norma Cossetto has become part of popular foibe legend and is featured in many other narratives. Gianni Oliva uses graphic detail similar to Petacco's to describe the Norma Cossetto story. The only cited source in his 2002 book, Foibe, is in fact Petacco, and Oliva's gory account is essentially a repetition of Petacco's earlier version. ${ }^{55}$ Oliva adds the stories of three more young women, three sisters who were arrested by Communist partisans and whose corpses, showing evidence of 'macabre mutilations', were discovered by the local priest, ${ }^{56}$ adding a subtle but effective connection between Italians and piety and referring to the unstated but implied pairing of Slavs with Communism, which can then be, and frequently is, reduced to godlessness.

Another instance of the Norma Cossetto story is Giuseppina Mellace's recent work Una Grande Tragedia Dimenticata,${ }^{57}$ which adds the stories of Dora Ciok and Mafalda Codan, following a similar pattern to that of Norma Cosetto: midnight abduction by Yugoslavian Communist partisans followed by days of torture and sexual violence. 'The martyrdom of Malfada doesn't finish here', Mellace writes midway through his description of the agony inflicted upon Malfada Codan, 'but Malfada did not let her pain win'. ${ }^{58}$ The young female martyr theme featured in these and other popular foibe narratives is brought to life, and into every Italian's living room, in Il cuore nel pozzo, a drama that aired on Italian television in 2005. The main character is Giulia, who throws herself into a foiba to save the son she bore after being raped by a Yugoslavian partisan. Mirroring Holocaust cinema's portrayal of Nazis, the Yugoslavian partisans in Il cuore nel pozzo wear heavy boots and uniforms and are accompanied by German Shepherds. ${ }^{59}$ This powerful combination of martyrdom imagery and Holocaust narrative makes a compelling front cover of Una Grande Tragedia Dimenticata, which depicts three armed partisans with red-starred hats, typical in portraits of Tito, holding a knife to the throat of a writhing victim, mouth open in pain as he is being forced into a foiba. The use of dimenticata in the title further emphasises the 'forgotten' character of the foibe, enhancing the construction of a submerged community, a counterpublic whose loss and suffering has not been properly recognised by the rest of the world.

In all the above examples, several images are meshed: the violated virgin, the Christian martyr and the gestapo soldier, recast as a Titoist. This combination of images reiterates the slavo-comunista trope, a theme which became prominent in Italy from 1946 onward $^{60}$ but is built upon earlier assumptions of innate Slavic predispositions towards Bolshevism and an inherent totalitarian character, one that is devoid of religion and God. ${ }^{61}$ The violence of the foibe, perpetrated by the Yugoslavian slavo-comunisti, can be represented as an attack on what is assumed to be the backbone of Italian society: civilisation, democracy and Catholicism. 


\section{Challenging the rhetoric of 'ethnic cleansing' and 'genocide'}

A few lesser-known authors challenge the prevailing foibe discourse with a small body of literature, websites and online journal articles, often published by smaller publishing houses with a left-wing affiliation. Literature by authors such as Burigo, Cernigoi, Kersevan and Volk, for example, counter the popular literature by citing a variety of sources to provide evidence that people of many ethnicities were targeted in the foibe killings. These authors also contextualise the foibe in the wider arena of violence that took place in the area at that time. Burigo argues that the 'ethnic cleansing' interpretation of the foibe is inaccurate and that the foibe were part of a climate of resa dei conti, a settling of scores that Burigo sees as a working and peasant class uprising. ${ }^{62}$ Italian members of the upper classes, according to Burigo, were among those targeted, but the Vigili del Fuoco from Pola also identified German soldiers among the corpses exhumed in 1943 from a 226 metre-deep foiba in Faraguni, a 125 metre-deep foiba in nearby Barban, and a 135 metre deep foiba in the village of Tinjan (all villages in Istria). ${ }^{63}$ Burigo questions the claims made in some narratives that carcasses of black dogs were found in the foibe alongside the human corpses. He believes these black dog stories have been added in order to advance the myth of the superstitious Slavs, who are presumed to believe that killing a black dog absolves guilt from the killer, or that a black dog prevents the soul of the person lying next to it from being admitted to Heaven and seeking revenge. ${ }^{64}$ The work of Claudia Cernigoi also refutes the black dog myth and ties it to stereotypes of primitive, superstitious Slavs. Both Burigo and Cernigoi argue that there is no evidence that dog carcasses were found in the foibe, and indeed the archival documents have no reports of dog carcasses. Cernigoi additionally argues that the Norma Cosetto story is purely a myth and was invented solely to create an Anne Frank equivalent. ${ }^{65}$

One of the most prolific and vocal challengers to the popular foibe narratives is Alessandra Kersevan, whose work compliments that of Cernigoi and Burigo and adds thorough investigations of specific foibe. One example is her well-researched analysis of Basovizza, the foibe that was named a national monument in 1992. Kersevan acknowledges that archival documents support evidence that bodies were disposed of in the Basovizza pit, but she cites testimonies from local inhabitants, including speleologists and members of the CLN, who report that the shaft was used by Nazi and Fascist forces to dispose of Slovene antifascists they executed. ${ }^{66}$ Kersevan has also documented a change in the inscription on the Basovizza monument. In 1996, the inscription on the monument read 'a section of 300 cubic meters contains infoibati corpses'. The inscription was adjusted the following year to read 'a section of 500 cubic meters contains infoibati corpses' ${ }^{67}$ Although the pit remained sealed and no actual explorations, measurements or exhumations took place between 1996 and 1997, the area reported to contain corpses was reported to have increased. This change reflects a blurring of actual exploration and reported 'fact'. Additionally, it indicates that discrepancies regarding the numbers of victims stem from political discussions framed in the 1990s, not the actual period of investigation in the immediate post-war years. 
Perspective, then, becomes one of the key problematic issues regarding the reporting of discoveries of foibe and corpses exhumed from them. Most of the popular foibe literature stems from post-1990s perspectives on war crimes, genocide and ethnic cleansing, with the breakup of Yugoslavia and the massacres that took place then fresh in public memory. Framing foibe discussions in light of those recent events facilitates an interpretation of the foibe violence as earlier versions of the same kind of ethnic cleansing mission, but one that was targeted against Italians. The foibe violence can thus be viewed as a precursor to the violence of the 1990s. To frame the foibe massacres in the context of 1943 and 1945, when the killings took place, requires a more attentive perspective, one that Gaia Baracetti approaches in her analysis of the foibe and of their heterogeneous interpretations. She asks, and proposes to examine, whether the victims were 'guilty of serious crimes and victims of an extreme but understandable popular reprisal against fascism? Or was it the massacre] rather a near-genocide that targeted innocents whose only crime was to be Italian in a land where Italians had become enemies to be expelled?' 68 She seems to be asking here whether we should take a 1943/1945 perspective or a 1990s perspective, one in which a number of ethnically-motivated genocides had gained international attention. Baracetti aims to go for the former. She examines the situational circumstances of the time, citing evidence that Italian and German forces used foibe to bury individuals they exterminated and pointing out that since many Slavic names were Italianised under Fascism, distinguishing who was actually Italian at the time of the foibe massacres was in many cases impossible. ${ }^{69}$ The ethnic cleansing argument falters under these conditions. Baracetti provides the following list of 1945 deportees from Trieste that she obtained from the archive of the Istituto Regionale per la Storia del Movimento di Liberazione in Friuli Venezia Giulia:

\author{
36 CLN members ${ }^{70}$ \\ 108 members of the Guardia di Finanza ${ }^{71}$ \\ 37 Italian army troops \\ 116 Italian civilians \\ 65 members of fascist militias \\ 118 members of other militias or police forces \\ 18 German soldiers and collaborators ${ }^{72}$
}

While the victims in the above list are for the most part Italians, it seems plausible that, as Baracetti states, the foibe were 'part of a wave of political violence sweeping all of Yugoslavia', a thorough cleansing of anti-Communists, and that being Italian put one at additional risk but was not the deciding factor. ${ }^{73}$ Baracetti also draws attention to one of the central problems with the ethnic cleansing argument: Communist ideology is conflated with a drive for Slavic dominance. The sweeping pairing of 'Slavs' with Communism ignores the complexities of the Yugoslavian communist revolution among the diverse ethnic and political Slavic populations within Yugoslavia, and associates Italians with resistance to Communist dictatorship. This minimises Fascism as a repressive political and military force and ignores the politically and militarily significant Italian resistance 
to Fascism. In so doing, foibe literature presents Italians as a persecuted minority for both political and ethnic reasons, fostering a conceptualisation of Italians as a counterpublic quite inaccurately during the Fascist years, as a minority among ethnic Slavs, then during the time of foibe violence, as a persecuted minority among Yugoslavian Communists, and today, as the forgotten victims of World War II.

\section{Conclusion}

Popular foibe literature has successfully presented the foibe massacres as acts of 'ethnic cleansing' against Italians, despite the lack of archival evidence to support this classification. The accuracy of archival documents is not completely unquestionable, since documents are often based on oral sources and are subject to errors of memory. ${ }^{74}$ But because military and governmental reports are presumably written at the time or closer to the time events are witnessed, their accuracy is more credible than highly politicised, unreferenced literature. Popular literature has nonetheless successfully perpetuated an 'ethnic cleansing' interpretation of the foibe massacres, fostering a nationwide acceptance of Italian-ness as an ethnicity and constructing a counterpublic identity for that constructed ethnic group. Ironically, the literature that challenges the 'ethnic cleansing' depiction of the foibe, little heard in the wider arena of popular literature, forms a counterpublic of its own, employing a narrative of victimhood to Slovenes and Croats in their experience of Fascist persecution and the accusation that they are to blame for the foibe violence. We might ask, then, who is more justified in claiming counterpublic status?

The resultant battle over who is most deserving of victimhood status has reduced the foibe massacres to a political tool, and the actual discovery, exhumation and reporting of corpses removed from the caves has retreated into obscurity. The association of the autotelic counterpublic status of the esuli with all Italians distorts the massacres even further, presenting the foibe as not only crimes against the esuli and their families but against all Italians. The political purpose this serves is clear: all Italians can adopt the identity of a submerged and subaltern group; a counterpublic, and a cohesive national identity can be forged. Italy's counterpublic identity submerges heterogeneous interpretations of the past, specifically Italy's uneasy relationship to Fascism and to its aggressor role in World War II. The growing popularity of foibe literature that advances Italy's counterpublic identity shows that this is a widely accepted notion. It is worth exploring, for future study, whether this literature has an audience outside of Italy and outside the field of Italian studies and, if so, how this literature is received by this audience. It will be interesting to see how discourse on the foibe evolves in the future. The political upheavals of the 1990 s ushered in a revision of Italy's interpretation of its World War II history; it is possible that the current decade of economic upheaval combined with its position in and relationship to the European Union might give rise to further revisionist interpretations of Italy's past. 


\section{Notes}

1 A. Burigo, 'La Questione delle Foibe del Settembre-Ottobre 1943 e del MaggioGiugno 1945: Analisi Critica delle Storiografia in Lingua Italiana e del Termine "Infoibati"', Annali di Studi Istriani e Mediterranei, 15:2 (2005), 309-26, 310; R. Pupo \& R. Spazzali (eds), Foibe (Milan, Mondadori Editori, 2003), p. 25; An additional wave of foibe killings in Zadar in October and November 1944 is described in L. Toth, 'Sulle Foibe in Venezia Giulia e in Dalmazia (1943-1950)', Clio: Rivista Trimestriale di Studi Storici, 42:3 (2006), 319-47. Most sources, however, only report the 1943 and 1945 episodes.

2 Foot states, '[T] he period immediately after liberation in particular was a time of the resa dei conti: the settling of accounts'. See J. Foot, Italy's Divided Memory (New York, Palgrave Macmillan, 2009), p. 168; Some of the most widely published accounts of post-war resa dei conti violence in Italy, from a right-wing and antiResistance perspective, are the works of Gianpaolo Pansa. See G. Pansa, Il Sangue dei Vinti: Quello Che Accadde in Italia Dopo 25 Aprile (Milan, Sperling \& Kupfer, 2003). Pansa's book, made into a popular film, was countered by the left-wing, pro-Resistance Il Sangue dei Vincitori (The Blood of the Victors). See M. Storichi, Il Sangue dei vincitori: Saggio sui crimini fascisti e i processi del dopoguerra, 1945-46 (Reggio Emilia, Alberti, 2008). These are only two examples of how a resa dei conti continues in Italy in the realm of World War II literature.

3 Burigo, 'La Questione delle Foibe', 310; G. Franzinetti, 'The Rediscovery of the Istrian Foibe', JGKS, History and Culture of South Eastern Europe, 8 (2006), 85-98; and P. Ballinger, History in Exile: Memory and Identity at the Borders of the Balkans, (Princeton, Princeton University Press, 2003), pp. 129-67, discuss the politically divisive issue of the use of the terms 'ethnic cleansing' and 'genocide' to describe the foibe killings. This terminology is exclusive to nationalistic political parties in Italy and has never been brought to an international stage.

4 A. Moodie, The Italo-Yugoslav Boundary: A Study in Political Geography (London, G. Philip \& Son Ltd, 1945), pp. 145, 158, 162-3.

5 L. Unger \& K. Šegulja, The Trieste Negotiations (Washington, The Johns Hopkins Foreign Policy Institute, 1990), pp. 29-39.

6 G. Sluga, The Problem of Trieste and the Italo-Yugoslav Border: Difference, Identity and Sovereignty in Twentieth-Century Europe (Albany, State University of New York, 2001), pp. 133-55.

7 Ballinger, History in Exile, pp. 81-93.

8 R. Michieli \& G. Zelco (eds), Venezia Giulia: la Regione Inventata (Udine, Kappa $\mathrm{Vu}, 2008)$.

9 P. Ginsborg, A History of Contemporary Italy: Society and Politics 1943-1988 (New York, Palgrave Macmillan, 2003), pp. 103-4.

10 Foot, Italy's Divided Memory, pp. 16, 34, 50, 51.

11 For the purposes of this essay I will compare archival documents from the United States National Archives in Washington to literature published in English and in Italian. I chose to limit my archival research to the documents from the United States for three reasons. Firstly, documents concerning the foibe from other 
archives, such as those in Trieste, Ljubljana and Belgrade are scarce and difficult to obtain, as many were destroyed in aftermath of World War II. Secondly, the Allied Military Command that controlled the region was primarily made up of American troops, and it was these troops who oversaw and documented many of the exhumation processes. Finally, the purpose of my research at this time is not to conduct an analysis of all available archival documents but to examine the discrepancy between archival documents and popular literature and to show how the popular literature serves a particular political purpose.

12 Counterpublic theory, defined by Nancy Fraser, Michael Warner and Robert Asen assumes the Habermasian public sphere necessarily gives rise to various 'subaltern counterpublics'. See N. Fraser, 'Rethinking the Public Sphere: A Contribution to the Critique of Actually Existing Democracy', Social Text, 25:26 (1990), 109-42; M. Warner, Publics and Counterpublics (New York, Zone Books, 2005); R. Asen, 'Ideology, Materiality, and Counter Publicity: William E. Simon and the Rise of a Conservative Counterintelligentsia', Quarterly Journal of Speech, 95:3 (2009), 263-88; Fraser defines a counterpublic as a self-organised and marginalised group whose discursive identity is different from the dominant public as defined by Habermas. The Habermasian 'public' is the arena of people who represent the community as a whole. Fraser argues that in any public sphere there will always be groups that are excluded by the discourse addressed to and by that public. Furthermore, all publics are inherently exclusive because societal structures of dominance and subordination always exist. See Fraser, 'Rethinking the Public Sphere', 116. A 'counterpublic' therefore emerges as a self-organised group whose discursive identity is different from that of the dominant public. The counterpublic's existence is often subordinate to and unrecognised by the dominant public. Counterpublic status may be based on gender, race, ethnicity, language, politics or other factors, but these identifiers alone do not create a counterpublic. Instead, counterpublics emerge due to the discursive needs of a particular group; they are autotelic, defined through the articulation of the identity needs of its members, and form through shared discourse. See Warner, Publics and Counterpublics, p. 70.

13 A. Petacco, Esodo: La Tragedia degli Italiani d'Istria, Dalmazia e Venezia Giulia (Milan, Mondadori Editori, 2000).

14 G. Oliva, Foibe: Le Stragi Negate degli Italiani della Venezia Giulia e dell'Istria (Milan, Mondadori Editori, 2002).

15 Toth, 'Sulle Foibe', 319-47.

16 G. Mellace, Una Grande Tragedia Dimenticata: La Vera Storia Delle Foibe (Rome, Newton Compton Editori, 2014).

17 A. Kersevan, 'La Malastoriografia. Esempi nella Mtoria del Confine Orientale', in D. Antoni (ed.), Revisionismo Storico e terre di Confine: Atti del corso di Aggiornamento, Trieste, 13 e 14 Marzo 2006 (Udine, Kappa Vu, 2006), pp. 173-94; A. Kersevan, 'I Campi di Concentramento Italiani per civili Jugoslavi', in Foibe, Revisionismo di Stato e Amnesie Della Repubblica (Udine, Kappa Vu, 2008), pp. 41-55.

18 C. Cernigoi, 'A Caccia di Bufale: La Ricerca Storica tra Leggende, Miti e Mere 
Falsificazioni', Dossier no.29, La Redazione de 'La Nuova Alabarda', 2008. URL: http://www.nuovaalabarda.org/leggi-articolo-wikipedia,_grande_bufala_dei_ nostri_tempi..php (accessed 15 December 2014); C. Cernigoi, 'Il Caso Norma Cossetto', Dossier no.38, La Redazione, 2011. URL: http://www.nuovaalabarda. org/leggi-articolo-il_caso_di_norma_cossetto..php (accessed 15 December 2014); C. Cernigoi, Operazione 'Foibe': Tra Storia e Mito (Udine, Kappa Vu, 2012), $165-6$.

19 S. Volk, 'Foibe ed Esodo, un Binomio da Sciogliere', in Foibe, Revisionismo di Stato e Amnesie Della Repubblica (Udine, Kappa Vu, 2008), 67-77, 67.

20 Burigo, 'La Questione delle Foibe', 320.

21 G. Baracetti, 'Foibe: Nationalism, Revenge and Ideology in Venezia Giulia and Istria, 1943-5', Journal of Contemporary History, 44 (2009), 657-74, 667.

22 Burigo, 'La Questione delle Foibe', 318.

23 See the 1946 statements by Kardelj and Kosanovic, making the case for the allocation of Trieste to Yugoslavia. First Statement in Trieste and the Julian March: The Original Yugoslav Government Memorandum on these subjects, London: Yugoslav Embassy Information Office, 11-24; E. Kardelj, Second Statement in Trieste and the Julian March: The Original Yugoslav Government Memorandum on These Subjects, London, Yugoslav Embassy Information Office, 37-49; See also Unger \& Šegulja, The Trieste Negotiations.

24 Volk, 'Foibe ed Esodo'.

25 Asen, 'Ideology, Materiality', 283.

26 The term 'Holocaustisation' is used by Franzinetti, 'The Rediscovery of the Istrian Foibe', 89.

27 National Archives at College Park, College Park, MD (NACP), National Archives Trust Fund, NWCT-2R/Room \#2710-2725, File No. 16-248-1, memo by A. Kirk, 22 June 1945.

28 NACP, AFHQ/A GSI (b); M 465 I, NWCT-2R/Room \#2710, memo by Eighth Army Headquarters to Secretary of State, 1 July 1945.

29 NACP, NWCT-2R/Room \#2710, File No. G-1/Br/15110/-3, 10 July 1945.

30 NACP, G1(Br)/15110/A3, NWCT-2R/Room \#2710, memo by Major General DAG, G-1 (Br) to Liet-Colonel Clarke, MC., British Embassy, Belgrade, Allied Force Headquarters, 19 July 1945. 'RACIA. J 0748 and MATTERIA. H. 9965' may refer to specific locations, yet the actual reference remains unclear. Despite this ambiguity, this memo clearly indicates the discovery of pits containing corpses in the vicinity of Basovizza, East of the Morgan Line.

31 NACP, NWCT-2R/Room \#2710, Nr.3037, memo by A. Kirk to the State Department 24 July 1945.

32 NACP, No. CM-IN 16186, No. 16-248. NW 563519, memo by General Somervell (10-45), 16 July 1945. There is in fact no location named 'Ternova Diccola', but the name could be a misprint of Ternova Piccola, a small village just outside of Trieste.

33 NACP, Nr. 3531, USA War Crimes Office, File 16-248, NWCT-2R/Room \#2710, memo by Gen. Somervell to Secretary of State, 6 September 1945. 


\section{Louise Zamparutti}

34 NACP, NWCT-2R/Room \#2710, MTO File 16-248, File No. 16176/1/A-3, MTO Case No. 167, memo by C. H. Porterfield, 26 Dec.1945.

35 A. Mihevc, 'Use of the Caves as Mass Graveyards in Slovenia', Karst Research Institute, Postojna, Slovenia. URL: http://cavernas.org.br/ anais26cbe/26CBE_499-503.pdf (accessed 1 December 2014).

36 Email from Andrej Mihevc, 23 November 2013.

37 Foiba is the singular and foibe the plural form of the Italian word for the deep vertical caves typical of the Karst region. The archives indicate finding corpses in these vertical caves; the word now carries tremendous political weight and no longer functions as a geomorphological term, as it refers to the killings and not to the caves themselves.

38 Toth, 'Sulle Foibe', 319. Toth generalises the foibe killings even further to include all anti-Italian violence that took place in Yugoslavia from 1943 to 1950.

39 Pupo \& Spazzali, Foibe, p. 4. Translation the author's own and italics added.

40 Ibid., p. 2.

41 See the individual chapter by T. Catalan, 'Nationalist Conflicts between Italians and Slavs at the End of the Hapsburg Empire' in Pupo \& Spazzali (eds), Foibe (Milan, Mondadori Editori, 2003), pp. 35-9.

42 See A. Vinci, 'The Politics of Fascism against the Slavs' in Pupo \& Spazzali (eds), Foibe (Milan, Mondadori Editori, 2003), pp. 40-4.

43 See two essays by Pupo in Pupo \& Spazzali, Foibe, pp. 45-8, 48-51.

44 Toth, 'Sulle Foibe', 319.

45 Ibid., 325.

46 Ibid., 335.

47 Ibid., 330.

48 Ibid., 338.

49 Ibid., 347.

50 The English translation of this title is Exodus: the Tragedy of the Italians of Istria, Dalmatia and Venezia Giulia.

51 Petacco, Esodo, p. 60.

52 Ibid., p. 60.

53 Ibid., p. 61.

54 Ibid., p. 62.

55 Oliva, Foibe, pp. 78-9.

56 Ibid., p. 79.

57 G. Mellace, Una Grande Tragedia Dimenticata: La Vera Storia Delle Foibe (Rome, Newton Compton Editori, 2014).

58 Mellace, Una Grande Tragedia Dimenticata, pp. 138-9.

59 S. Knittel, 'Memory Redux: The Foibe on Italian Television', The Italianist, 34:2 (2014), 170-85, 175.

60 Ballinger, History in Exile, p. 88, from Ballinger's personal communication with G. Valdevit.

61 Ballinger, History in Exile, p. 66; See also G. Sluga, The Problem of Trieste and the Italo-Yugoslav Border (Albany, State University of New York Press, 2001), pp. 154-6, for a thorough discussion of this theme. 
62 Burigo, 'La Questione delle Foibe', 310.

63 Ibid., 315.

64 Ibid., 314.

65 Cernigoi, 'Il Caso Norma Cossetto'.

66 Cernigoi, Operazione 'Foibe', pp. 165-6.

67 Kersevan, 'La malastoriografia', p. 187.

68 G. Baracetti, 'Foibe: Nationalism, Revenge and Ideology in Venezia Giulia and Istria, 1943-5', Journal of Contemporary History, 44 (2009), 657-74, 657.

69 Ibid., 660.

70 Committees of National Liberation, one of the principal organisational groups of the Italian Resistance.

71 A specialised branch of the Italian police force.

72 Baracetti, 'Foibe', 666. This cites Document 2228 in the archive of the Istituto Regionale per la Storia del Movimento di Liberazione nel Friuli Venezia Giulia.

73 Ibid., 667.

74 Foot, Italy's Divided Memory, p. 5. 